\title{
The Benefits of Identifying and Treating Adrenal Suppression in Adult Difficult Asthmatics: A Case Series
}

\author{
Veronica A. Varney*, Helen Parnell, Ginny Quirke \\ Respiratory Department, St. Helier Hospital, Wrythe Lane, Carshalton, Surrey, UK \\ Email: *veronica.varney@esth.nhs.uk, Helen.parnell@esth.nhs.uk,ginny.quirke@esth.nhs.uk
}

Received 5 March 2016; accepted 14 May 2016; published 17 May 2016

Copyright (C) 2016 by authors and Scientific Research Publishing Inc.

This work is licensed under the Creative Commons Attribution International License (CC BY).

http://creativecommons.org/licenses/by/4.0/

(c) (i) Open Access

\begin{abstract}
We present 7 adults atopic asthmatics that were referred due to repeatedly relapsing asthma requiring oral courses of prednisolone. All were steroid responsive yet steroid dependant and were screened for adrenal insufficiency after changes to inhaled therapy and other standard antiasthma treatments failed to improve the situation. All were deemed to be compliant. 4 used longterm intranasal steroids in addition to inhaled corticosteroids. No topical steroid creams were used by these patients. Adrenal suppression was examined via a 9 am cortisol level and a short synacthen test (using intravenous tetracosactide $250 \mathrm{mcg}$ ) along with measurement of ACTH (Adreno-Cortico-Trophic Hormone). The tests were performed in periods off prednisolone. We report the observed beneficial effects after treatment of the adrenal insufficiency with hydrocortisone acetate replacement therapy in these cases, and the benefit to their exacerbations, hospital admission and the requirement for prednisolone courses. These patients would have been stepped up to yet higher doses of inhaled steroids and even referred for anti-IgE treatment etc. Adrenal suppression is well described in the medical literature for asthmatics, but the beneficial outcomes of treating this are unknown. These 7 cases have been followed for up to 3 years since hydrocortisone replacement therapy. Most improved to a stable asthma without frequent exacerbations nor requirement for prednisolone and only 1 had a hospital admission.
\end{abstract}

\section{Keywords}

Difficult Asthma, Steroid Dependence, Adrenal Suppression, Atopy, Chronic Rhinitis, Adrenal Replacement Therapy

\footnotetext{
${ }^{*}$ Corresponding author.
} 


\section{Introduction}

Adrenal suppression is the inadequate production of cortisol under physiological stress. It is rare in the general population and may present in a non-specific way [1]. Adrenal suppression as a consequence of oral corticosteroids was well recognized by the 1960's and became further apparent in asthmatics when oral steroids were weaned to Inhaled Corticosteroids (ICS) in the 1970's [2]. In the early days of ICS treatment for asthma, adrenal suppression from ICS was believed to be rare and a similar view was taken for Intranasal Steroids (NCS) [3] [4]. There are now over 60 case reports in the literature of ICS-induced adrenal suppression, mostly in children presenting in adrenal crisis (hypoglycaemia, hypotension, coma and fits); while some children presented with poor weight gain and growth [1] [5]-[7]. 91\% of these cases involved the use of high dose (>500 $\mu$ g) Fluticasone Propionate (FP) and it was believed that children may be more susceptible to adrenal suppression than adults [2] [3] [8]-[10].

In adults, presentations with acute adrenal crisis involving ICS is rare and few specific symptoms are recognised, although biochemical evidence may be present. It is now accepted that high dose ICS do suppress the Hypothalamic Pituitary Adrenal (HPA) axis [7] [11]. 90\% of deposited ICS is into the oral pharyngeal area and can be absorbed via the gut. There is generally a high first pass metabolism of gut absorbed steroids, but variation in this could explain susceptibility to adrenal suppression [11].

Delivery of ICS via a large volume spacer $(750 \mathrm{mls})$ has been shown to reduce biochemical adrenal suppression with improved 9 am cortisol and improved "Synacthen stimulation test results" (using tetracosactide 250 mcg) after 10 weeks of volumatic use [11].

It is now believed that adrenal suppression may be significantly under estimated in patients with difficult asthma. At Leeds “difficult asthma clinic” in the United Kingdom, 8.7\% of referred patients not taking oral prednisolone, had insufficient random cortisol levels with values below $<50 \mathrm{nmol} / \mathrm{l}$ instead of an expected value above $120 \mathrm{nmol} / \mathrm{l}$. These random cortisols were used as a guide to further investigation for adrenal insufficiency including early morning cortisol [4].

In 2006, a very large case control study of ICS and oral steroids and their effects on adrenal insufficiency was published [2]. This study quantified the risk and showed a dose response relationship. Univariant analysis showed a single course of oral prednisolone to double the risk of adrenal insufficiency. This risk was dose related with an odds ratio of 2.0 per prednisolone course per year. After adjusting for oral prednisolone courses, ICS also increased the risk with an odds ratio of 1.3 after 90 days of continuous treatment [2].

Previous studies have suggested that Intranasal Corticosteroids (NCS) have minimal effects on the HPA axis. The proportion of NCS that undergoes first pass metabolism is lower than ICS due to direct mucosal absorption and greater systemic concentrations especially for children, who often receive a higher $\mu g$ per Kg dosage than adults [12]-[14].

A study of ICS and NCS in children examined by a logistic regression model for HPA suppression showed daily ICS with NCS to have the greatest risk; with log daily nasal steroid dose the most significant predictor, due to direct systemic absorption through the nasal mucosa with an odds ratio of 3.7 for adrenal suppression with NCS [7]. They found the prevalence of adrenal suppression to be 35\% in children on ICS and NCS with HPA axis suppression occurring after 6 - 42 months on treatment. Obesity appeared protective as was a degree of noncompliance with ICS and NCS medication. The FEV-1/FVC ratio was found to be the only lung function significantly associated with HPA suppression and independent of cumulative dose of ICS and NCS. A child with a FEV-1/FVC ratio of $<80 \%$ was four times more likely to have developed HPA suppression than those $>80 \%$. No correlation with HPA suppression and the number of oral steroid courses in the preceding year was recognised in these children [7]. The patterns of our presented cases are similar, with all cases showing relapsing asthma that appeared steroid sensitive yet steroid dependant, as will be seen from the case histories presented.

Currently no case studies describe whether recognising and treating underlying adrenal insufficiency has beneficial effects in difficult asthma. In this case series we followed 7 patients on adrenal replacement therapy for 2 - 3 years and assessed the impact on their asthma exacerbations, steroid courses and hospital admissions. All gave their written informed consent.

\section{Case 1 (Table 1)}

Referred with difficult atopic asthma of 12 months duration prior to which she had been easily controlled in adulthood by inhaled seretide (1000 $\mu$ g daily) for 15 years. In addition, she had "santers triad” with aspirin allergy, 
Table 1. Cases 1-4, demographics of presented cases.

\begin{tabular}{|c|c|c|c|c|}
\hline Cases & 1 & 2 & 3 & 4 \\
\hline Age (sex) & $49(\mathrm{~F})$ & $49(\mathrm{~F})$ & $45(\mathrm{~F})$ & $54(F)$ \\
\hline Ethic group & Caucasian & Caucasian & Caucasian & Caucasian \\
\hline Smoking (pack yrs) & Ex 4 yrs (15) & Ex 5 yrs (10) & Ex 9 yrs (25) & Ex-3 (40) \\
\hline Main complaint & Exacerbating asthma & Exacerbating asthma & Exacerbating asthma & Exacerbating asthma \\
\hline $\begin{array}{l}\text { Past medical } \\
\text { history }\end{array}$ & $\begin{array}{l}\text { Atopic asthma } \\
\text { Aspirin allergy } \\
\text { Chronic rhinosinusitis } \\
\text { Nasal polyps } \\
\text { polypectomies }\end{array}$ & $\begin{array}{l}\text { Atopic asthma } \\
\text { Rhinosinusitis } \\
\text { Nasal polyps } \\
\text { Otitis media } \\
\text { Vocal cord nodules } \\
\text { polypectomies }\end{array}$ & $\begin{array}{c}\text { Atopic asthma } \\
\text { Hayfever } \\
\text { Hypersensitivity pneumonitis } \\
\text { Depression and anxiety } \\
\text { Iron deficiency } \\
\text { GERD } \\
\text { Obesity, } \uparrow \text { cholesterol }\end{array}$ & $\begin{array}{c}\text { Atopic asthma } \\
\text { Vocal cord dysfunction } \\
\text { Lumbar disc disease } \\
\text { depression } \\
\text { hypothyroid } \\
\text { high cholestrol }\end{array}$ \\
\hline Atopic & Grass mites tree moulds & Grass tree mites moulds & Grass cat & Grass, dander, mites \\
\hline $\begin{array}{l}\text { Duration of asthma } \\
\text { (yrs) }\end{array}$ & 34 & lifelong & 15 & 30 \\
\hline $\begin{array}{l}\text { Duration of difficult } \\
\text { asthma (months) at } \\
\text { referral }\end{array}$ & 12 & 18 & 12 & 18 \\
\hline $\begin{array}{l}\text { Total daily dose inhaled } \\
\text { steroids }(\mu \mathrm{g})\end{array}$ & 1000 & 1600 & 2000 & 1600 \\
\hline Medication & $\begin{array}{c}\mathrm{FP} / \text { serevent }^{+} \\
\text {Betnosol nasal drops } \\
\text { Montelukast } \\
\text { doxycycline }\end{array}$ & $\begin{array}{c}\text { BDP/formoterol } \\
\text { montelukast } \\
\text { Betnosol } \\
\text { Doxycycline } \\
\text { Vitamin D }\end{array}$ & $\begin{array}{c}\text { BDP/formoterol } \\
\text { BDP (extra without formoterol) } \\
\text { Simvastatin } \\
\text { Omeprazole } \\
\text { amitriptyline }\end{array}$ & $\begin{array}{c}\text { BDP/formoterol } \\
\text { tiotropium } \\
\text { aminophylline } \\
\text { carbocisteine } \\
\text { lansoprazole } \\
\text { salbutamol } \\
\text { fluoxetine } \\
\text { thyroxine }\end{array}$ \\
\hline $\begin{array}{l}\text { Regular use of nasal } \\
\text { steroids }\end{array}$ & Yes & Yes & Seasonal & No \\
\hline $\begin{array}{l}\text { Duration of rhinitis } \\
\text { (yrs) }\end{array}$ & 34 yrs & $20 \mathrm{yrs}^{+}$ & Seasonal & None \\
\hline $\begin{array}{l}\text { Regular need for oral } \\
\text { steroids (yrs) prior to } \\
\text { referral }\end{array}$ & $1 \mathrm{yr}$ & $1.5 \mathrm{yr}$ & $1 \mathrm{yr}$ & 4 yrs \\
\hline $\begin{array}{c}\text { Best PEFR } \\
\text { (\% predicted) }\end{array}$ & $93 \%$ & $125 \%$ & $97 \%$ & $85 \%$ \\
\hline $\begin{array}{l}\text { Best FEV-1 } \\
\text { (\% predicted) }\end{array}$ & $95 \%$ & $97 \%$ & $80 \%$ & $86 \%$ \\
\hline $\begin{array}{c}\text { Best FVC } \\
\text { (\% predicted) }\end{array}$ & $85 \%$ & $96 \%$ & $90 \%$ & $82 \%$ \\
\hline $\begin{array}{l}\text { 9am cortisol (normal } \\
\text { range } 250 \text { - } 450 \mathrm{nmol} / \mathrm{l})\end{array}$ & 11 & 120 & 129 & 11 \\
\hline $\begin{array}{c}\text { Synacthen test (Cortisol } \\
\text { rise at } 30 \\
\text { minutes nmol/l) }\end{array}$ & 20 & 69 & 46 & 99 \\
\hline $\begin{array}{c}\text { ACTH level during } \\
\text { synathen test ng/l } \\
\text { (normal range } 10 \text { - } 50 \\
\text { ng/l) }\end{array}$ & $<5$ & $<5$ & 24 & $<5$ \\
\hline $\begin{array}{l}\text { Hydrocortisone } \\
\text { replacement dose in mg } \\
\text { daily }\end{array}$ & 20 & 30 & 20 & 30 \\
\hline $\begin{array}{c}\text { No of exacerbations } \\
\text { since hydrocortisone } \\
\text { treatment }\end{array}$ & 0 & 0 & 0 & 1 \\
\hline $\begin{array}{l}\text { No. of steroid courses } \\
\text { since hydrocortisone } \\
\text { acetate commenced }\end{array}$ & 0 & 0 & 0 & 1 \\
\hline $\begin{array}{l}\text { Duration of follow-up } \\
\text { on hydrocortisone }\end{array}$ & 3 yrs & $2.5 \mathrm{yr}$ & 3 yrs & $1.5 \mathrm{yrs}$ \\
\hline $\begin{array}{l}\text { Hospital admissions } \\
\text { Since hydrocortisone }\end{array}$ & Nil & Nil & Nil & 1 \\
\hline
\end{tabular}

${ }^{+}$GERD: Gastro-Oesophageal Reflux; ${ }^{+}$BDP: Budesonide Propionate; ${ }^{+}$FP: Fluticasone Propionate. 
nasal polyps and asthma. She had smoked until 4 years before and described her asthma as well controlled during her time in the UK.

When her asthma began at 16 years in Russia, she was left on oral prednisolone for 15 years, but weaned herself off prednisolone by age 30. After coming to the UK and commencing ICS-FP, she took no oral steroids, but did have constant betnesol nasal drops for her polyps. Her polyps had been a life long problem with regular Ear Nose and Throat (ENT) attendances and many polypectomies. Her last operation had been just before referral. Her CT scan showed extensive sinus disease. She was taking regular doxycycline for "repeat otitis media".

She described repeat infections of the chest with tightness and wheeze and sinus pain and felt feverish and would commence oral prednisolone. At her first attendance for the difficult asthma she was taking montelukast $10 \mathrm{mg}$ and FP $1000 \mathrm{mcg} / \mathrm{day}$. Her inhaler technique was corrected and she commenced oral vitamin D. Immune tests were normal. Skin prick tests showed her to be atopic (see Table 1).

Her chest X-ray was clear and spirometry essentially normal. Her frequent courses of prednisolone and persistent asthma relapse over 12 months had led to her referral.

She denied fatigue or exhaustion otherwise and said she was always energetic and worked as a teacher.

Her asthma stabilized with adjustments of medication and a change to BDP/formoterol combination (800 $\mu \mathrm{g})$. Finally, she attended "prednisolone free" for her 9 am cortisol level. This returned at $11 \mathrm{nmol} / \mathrm{l}$ (normal range 250 - 450) which was confirmed on repeat measurement.

A "Synacthen" test confirmed a wholly inadequate adrenal response and she was commenced on hydrocortisone acetate replacement. This stabilised her asthma without further oral prednisolone courses and she was well and all fever-like sensations ceased and oral antibiotics for the sinuses were stopped. Her frequent outpatient reviews ceased and were only needed for her hydrocortisone day curves. After stabilising her asthma, she was commenced on oral aspirin desensitization for her nasal polyps, and this resolved most of her ENT problems. It was felt that her nasal steroids over many years had added to the adrenal suppression.

\section{Case 2 (Table 1)}

A 49 years old lady referred with difficult asthma. She had long term nasal polyps and atopy from childhood, with a polypectomy 7 months before referral. She also had a history of longterm otitis media treated with doxycycline. Her chest $\mathrm{X}$-ray was normal and she used regular symbicort and montelukast. Her father and siblings were also atopic asthmatics. She gave up smoking 4 years before.

She was in a cycle of asthma exacerbations, which responded well to oral prednisolone but relapsed within 2 weeks of their cessation. There would be an increase in chest tightness and wheeze and falling spirometry which was completely reversed by prednisolone.

Her skin tests showed her to be atopic. No immune deficiency was present on blood tests and her inhaler technique was good and compliance confirmed by her GP. She had long-term NCS for her polyps.

When first referred it was the grass pollen season, which could have explained her exacerbations, but even with house dust mite measures asthma control was difficult.

After 1 year of efforts to stabilize her asthma, a 9 am cortisol level was measured when off prednisolone. Her 9 am cortisol was low (Table 1 ) and the synathen test was equally abnormal. She was commenced on hydrocortisone acetate replacement.

Her asthma relapses ceased and she had no further oral steroids and was clinically stable. Her nasal polyps also improved. After feeling so well for 2 years she decided on holiday in Australia to discontinue her hydrocortisone acetate and within 1 week developed increased cough and wheeze with a fall in peak flow and returned to her treatment.

\section{Case 3 (Table 1)}

This 45 years old lady was referred in 2008 with subacute hypersensitivity pneumonitis (HP) with the onset after commencing an antidepressant (citalopram $20 \mathrm{mg}$ ). She had crackles in the lung fields with desaturation on walking and shadowing on her chest X-ray. Hypersensitivity pneumonitis was diagnosed on her HRCT chest scan.

She had mild atopic asthma which troubled her only in the grass pollen season. She had been treated with prednisolone for 9 months during 2008 on a weaning course with resolution of the HP condition and her SSRI was discontinued. She was reassured and discharged. 
In June 2011, she was re-referred by her GP for breathlessness and wheeze for which she had already been commenced on oral prednisolone for 5 weeks. Her Chest X-ray was clear with no crackles in the lung field and no desaturation on exertion. No spirometry had been measured prior to the steroids being commenced and it was also the grass pollen season. In addition, she had recently re-commenced the same anti-depressant! Now the medical literature did contain reports of HP reactions to this drug not reported back in 2008. The drug was again stopped and substituted with a tricyclic antidepressant. Oral prednisolone was reduced and stopped after the grass pollen season.

At that stage her asthma continued to be problematic and relapsing without the influence of pollen or viruses and remained difficult for 2 years with frequent outpatient attendances.

In 2013, it was decided to measure her 9 am cortisol which returned low and a Synacthen test confirmed adrenal insufficiency. On hydrocortisone acetate replacement, asthma completely stabilised. The grass pollen "asthma” was then treated by pre-seasonal grass pollen desensitization with great benefits and no prednisolone use was required in the grass season. She has remained stable without any further problems with her asthma.

\section{Case 4 (Table 1)}

A 51 years old lady with a 30 years history of atopic asthma, which had been difficult to control for 18 months. She needed repeat courses of prednisolone for monthly exacerbations which became almost continuous with reduced spirometry along with cough and wheeze. She was unable to go to work for 6 months due to her degree of breathlessness and wheeze. She had still been smoking a few cigarettes and had struggled to completely stop. Upon referral, her GP had attributed the low spirometry to COPD rather than asthma. Medication and inhaler techniques were adjusted and maximised but she remained prednisolone dependant.

The likelihood of adrenal suppression was raised and a 9 am cortisol and synathen test were measured off prednisolone and shown to be abnormal (Table 1). She was commenced on hydrocortisone acetate replacement and her prednisolone requirement reduced and her asthma stabilised.

She returned to work and her spirometry recovered (Table 1). She found taking the hydrocortisone acetate three times a day difficult to remember leading to 2 exacerbations which reinforced her compliance. In the 2.5 years follow up she has complete ceased all smoking and her asthma has remained stable.

\section{Case 5 (Table 2)}

A 59 years old post office worker with atopic asthma for $>10$ years which was associated with perennial rhinitis, nasal polyps and aspirin allergy (santers triad). He was referred due to unstable asthma for 3 years by his GP. He had bronchospasm with a reduced PEFR along with sinus pain and discharge for which he took long-term doxycycline. He remained on prednisolone for most of 2013, relapsing if doses went below $10 \mathrm{mg}$ despite maximal adjustment to other asthma therapy (Table 2). A 9 am cortisol and synathen test when off prednisolone was abnormally low. On hydrocortisone replacement the use of prednisolone ceased except for viral exacerbations, but he still had episodes of chest tightness and ongoing problems from his nasal polyps.

With improved asthma stability he was commenced on oral aspirin desensitization which stabilized these episodes of bronchospasm with improvement in his symptoms of nasal obstruction and quality of life for the first time in many years.

\section{Case 6 (Table 2)}

A 51 years old lady, with known atopic asthma and chronic rhinosinusitis for many years. For her nasal disease she used topical steroids and douching. Her asthma had been relapsing over the preceding 21 months with frequent episodes of cough and wheeze which improved with prednisolone. Following referral her asthma treatment was maximised and compliance was good. Tiredness was described off prednisolone along with relapses of her asthma by 2 weeks off treatment. This led to checking of a 9 am cortisol level and synathen test. Adrenal insufficiency was confirmed (Table 2) and she was commenced on hydrocortisone acetate. Her asthma completely stabilised and prednisolone requirements ceased and she remained free of further asthma exacerbations since the treatment.

\section{Case 7 (Table 2)}

A 48 years old nurse, whose prior stable asthma had been difficult to control for 2 years. He suffered frequent 
Table 2. Cases 5-7, demographics of presented cases.

\begin{tabular}{|c|c|c|c|}
\hline Cases & 5 & 6 & 7 \\
\hline Age (sex) & $59(\mathrm{M})$ & $51(\mathrm{~F})$ & $48(\mathrm{M})$ \\
\hline Ethic group & Indian & Caucasian & Caucasian \\
\hline Smoking (pack yrs) & No & No & No \\
\hline Main complaint & Exacerbating asthma & Exacerbating asthma & Exacerbating asthma \\
\hline Past medical history & $\begin{array}{c}\text { Asthma } \\
\text { Nasal polyps/rhinitis } \\
\text { Aspirin allergy }\end{array}$ & $\begin{array}{c}\text { Sinusitis } \\
\text { Atopic asthma } \\
\text { Polycystic ovary syndrome } \\
\text { HTN, GERD } \\
\text { VCD }^{+}\end{array}$ & $\begin{array}{l}\text { Asthma from childhood } \\
\text { hay fever }\end{array}$ \\
\hline Atopic & Aspirin grass & Mites, pollen, dander & Grass \\
\hline Duration of asthma (yrs) & 10 & 12 & 45 \\
\hline Duration of difficult asthma (months) at referral & 72 & 21 & 24 \\
\hline Total daily dose inhaled steroids $(\mu \mathrm{g})$ & 800 & 1000 & 1000 \\
\hline Current medication $^{+}$ & $\begin{array}{c}\text { BDP/formoterol } \\
\text { Avamys nasal spray } \\
\text { montelukast }\end{array}$ & $\begin{array}{l}\text { FP/formoterol } \\
\text { Salbutamol } \\
\text { Losartan } \\
\text { Indapamide } \\
\text { Montelukast } \\
\text { Mirtazepine } \\
\text { Momentasone }\end{array}$ & $\begin{array}{c}\text { FP/serevent } \\
\text { Montelukast } \\
\text { cetirizine }\end{array}$ \\
\hline Regular use of nasal steroids & Yes & Yes & Seasonal \\
\hline Duration of rhinitis (yrs) & Lifelong & 6 & Lifelong \\
\hline Regular need for oral steroids (yrs) & $4 \mathrm{yrs}$ & 2 yrs & $2 \mathrm{yrs}$ \\
\hline Best PEFR (\% predicted) & $75 \%$ & $85 \%$ & $77 \%$ \\
\hline Best FEV-1 (\% predicted) & $59 \%$ & $76 \%$ & $59 \%$ \\
\hline Best FVC (\% predicted) & $69 \%$ & $82 \%$ & $82 \%$ \\
\hline 9 am cortisol nmol/l (normal range 250 - 450 nmol/l) & 35 & 5 & 62 \\
\hline Synacthen test rise at 30 minutes $\mathrm{nmol} / \mathrm{l}$ & 178 & 191 & 170 \\
\hline $\begin{array}{l}\text { ACTH level during synathen test ng/l (normal range } \\
\qquad 10-50 \mathrm{ng} / \mathrm{l})\end{array}$ & 7 & 7 & 14 \\
\hline Hydrocortisone replacement mg daily dose & $15 \mathrm{mg}$ & 30 & 10 \\
\hline No of exacerbations since hydrocortisone treatment & 2 viral & 0 & 4 \\
\hline $\begin{array}{l}\text { No. of steroid courses since hydrocortisone acetate } \\
\text { commenced }\end{array}$ & $\begin{array}{l}2 \text { short courses post viral } \\
\text { Activation }\end{array}$ & 0 & 4 \\
\hline Duration of follow-up on hydrocortisone & $2.5 \mathrm{yrs}$ & 2.5 & $2.5 \mathrm{yrs}$ \\
\hline Hospital admissions since hydrocortisone & Nil & Nil & Nil \\
\hline
\end{tabular}

${ }^{+}$HTN: Hypertension; ${ }^{+}$GERD: Gastro-Oesophageal Reflux Disease; ${ }^{+}$VCD: Vocal Cord Dysfunction; ${ }^{+}$BDP: Budesonide Propionate; ${ }^{+}$FP: Fluticasone Propionate.

exacerbations requiring back to back courses of prednisolone despite review and adjustment of regular asthma medication and compliance. Adrenal function was checked and his 9 am cortisol was low and the synathen test impaired. He was therefore commenced on hydrocortisone acetate replacement with adjustment according to his hydrocortisone day curves. This settled his frequent exacerbations, with only 4 short courses for prednisolone over the last 2.5 years for viral exacerbations.

\section{Discussion}

All 7 cases demonstrated steroid sensitive yet steroid dependant asthma with oral steroids required every 2 - 4 weeks with relapse upon their cessation. All had frequent outpatient appointments for asthma and half used regular NCS. No specific symptoms of adrenal suppression were described such as fatigue or exhaustion [2]. All 
were tested for adrenal suppression once off prednisolone following a clinical decision to rule out the condition. 9 am cortisols were low and a stimulation test with tetracosactide was arranged in the medical investigation unit. The tetracosactide test (250 mcg) [12] was performed between 8-10 am with a 30 minute cortisol and ACTH level taken. A cortisol rise of $200 \mathrm{nmol} / \mathrm{l}$ above the baseline at 30 minutes is a normal response. None of these patients achieved that value.

When treated with hydrocortisone acetate replacement in divided doses ( $8 \mathrm{am}, 2$ \& 5 pm), was commenced their relapsing asthma resolved. They were seen by our endocrinologists and their hydrocortisone day curve assessed after 4 weeks on treatment. All patients gave low but adequate hydrocortisone day curves which showed no over-treatment with hydrocortisone. This halted the requirement for repeated oral prednisolone rescue.

Outpatients and GP visits which had been frequent, were now reduced dramatically to those required only to monitor the asthma routinely and review the hydrocortisone day curve results with adjustments if indicated. 2 patients were able to embark on oral aspirin desensitization to assist their nasal polyposis. Case 3 was stable enough to have sublingual immunotherapy for her severe grass pollen allergy with great benefit. Over the 3 year follow-up, half the cases were able to reduce their hydrocortisone acetate by 5 or $10 \mathrm{mg}$ a day, but none have recovered their adrenal function. Recognising and treating the adrenal suppression has clearly improved their life quality and made most cases easy to manage with prednisolone limited to viral exacerbations instead of monthly courses.

Adrenal insufficiency screening was fruitful especially as most of these cases could have been referred to difficult asthma clinics for consideration of anti-IgE therapy.

Much is written about high dose FP as a risk for adrenal suppression in children at doses > $500 \mu /$ day [1] [6]. Cicesonide like FP has high receptor binding but no adrenal suppression is reported due to it high blood protein binding at 99\%, leaving only 1\% biologically active [3] [10]. A 10-fold difference from that seen with FP [1]! The level of ICS-plasma protein binding inversely correlates with the degree of adrenal suppression. For budesonide propionate (BDP) the shorter half-life of 2 - 3 hrs [1] [15] and lower glucocorticoid receptor residency time, means that much higher doses are required for adrenal suppression in adults and children compared with FP [1] [16].

Analysis of these 7 cases showed similar potential risk factors for adrenal suppression due to inhaled ICS, NCS and repeated courses of oral prednisolone due to relapsing asthma. No cases reported any recognised symptoms of adrenal insufficiency or adrenal crisis when off oral prednisolone, but simply demonstrated a relapse of asthma. Most cases remained in a cycle of prednisolone courses every 2 - 4 weeks. This pattern was clearly the sign of insufficiency in these patients.

\section{Conclusion}

These adult asthmatics presented as difficult asthma that relapsed continuously once oral prednisolone ceased. There was high demand for regular asthma reviews in outpatients. Recognising and treating adrenal suppression stabilized their asthma, with most cases showing maintained improvement throughout the 3-year follow up. This could support an approach for screening adults with difficult asthma in case this is one manner in which the condition of adrenal suppression does manifest.

\section{References}

[1] Ahmet, A., Kim, H. and Spier, S. (2011) Adrenal Suppression: A Practical Guide to the Screening and Management of the Under-Recognised Complications of Inhaled Corticosteroids Therapy. Allergy, Asthma \& Clinical Immunology, 7, 13-18. http://dx.doi.org/10.1186/1710-1492-7-13

[2] Mortimer, K.J., Tata, L.J., Smith, C.J.P., West, J., Harrison, T.W., Tattersfield, A.E. and Hubbard, R.B. (2006) Oral and Inhaled Corticosteroids and Adrenal Insufficiency: A Case-Control Study. Thorax, 61, 405-408. http://dx.doi.org/10.1136/thx.2005.052456

[3] Todd, G.R.G., Wright, D. and Ryan, M. (1999) Acute Adrenal Insufficiency in a Patient with Asthma after Changing from Fluticasone Propionate to Budesonide. Journal of Allergy and Clinical Immunology, 103, 956-957. http://dx.doi.org/10.1016/S0091-6749(99)70447-1

[4] Sutherland, T.J.T., Hodgekiss, C., Slough, J., Barth, J.H. and Clifton, I.J. (2012) Adrenal Suppression in Difficult Asthma: A Neglected Cause for Concern. Thorax, 67, A67. http://dx.doi.org/10.1136/thoraxjnl-2012-202678.150

[5] Taylor, A.V., Laoprasert, N., Zimmerman, D. and Sachs, M.I. (1999) Adrenal Suppression Secondary to Inhaled Fluti- 
casone Propionate. Annals of Allergy, Asthma \& Immunology, 83, 68-70. http://dx.doi.org/10.1016/S1081-1206(10)63515-6

[6] Havill, S. (2013) Poorly Recognised Adverse Effects of Inhaled Corticosteroids. Prescriber Update, 16, 16-19.

[7] Zollner, E.W., Lombard, C.J., Galal, U., Hough, S., Irusen, E.M. and Weinberg, E. (2012) Hypothalamic-PituitaryAdrenal Axis Suppression in Asthmatic School Children. Pediatrics, 130, 1512-1519. http://dx.doi.org/10.1542/peds.2012-1147

[8] Sim, D., Griffiths, A., Clarke, C., Rodda, C. and Freezer, N. (2003) Adrenal Suppression from High-Dose Fluticasone Propionate in Children with Asthma. European Respiratory Journal, 21, 633-636. http://dx.doi.org/10.1183/09031936.03.00306302

[9] Todd, G., Dunlop, K., McNaboe, J., Ryan, M.F., Carson, D. and Shields, M.D. (1996) Growth and Adrenal Suppression in Asthmatic Children Treated with High-Dose Fluticasone Propionate. Lancet, 348, 27-29. http://dx.doi.org/10.1016/S0140-6736(96)03339-9

[10] Kaliner, M.A. (2006) Pharmacologic Characteristics and Adrenal Suppression with Newer Inhaled Corticosteroids: A Comparison of Ciclesonide and Fluticasone Propionate. Clinical Therapeutics, 28, 319-331. http://dx.doi.org/10.1016/j.clinthera.2006.03.003

[11] Brown, P.H., Blundell, G., Greening, A.P. and Crompton, G.K. (1990) Do Large Volume Spacer Devices Reduce the Systemic Effects of High Dose Inhaled Corticosteroids? Thorax, 45, 736-739. http://dx.doi.org/10.1136/thx.45.10.736

[12] Bruni, F.M., De Luca, G., Venturoli, V. and Boner, A.L. (2009) Intranasal Corticosteroids and Adrenal Suppression. Neuroimmunomodulation, 16, 353-362. http://dx.doi.org/10.1159/000216193

[13] Lipworth, B.J. (1999) 24 Hour and Fractionated Profiles of Adrenocortical Activity in Asthmatics Patients Receiving Inhaled and Intranasal Corticosteroids. Thorax, 54, 20-26. http://dx.doi.org/10.1136/thx.54.1.20

[14] Gill, G., Swift, A., Jones, A., Strain, D. and Weston, P. (2001) Severe Adrenal Suppression by Steroid Nasal Drops. Journal of the Royal Society of Medicine, 94, 350-351.

[15] Clark, D.J. and Lipworth, B.J. (1997) Adrenal Suppression with Chronic Dosing of Fluticasone Propionate Compared with Budesonide in Adult Asthmatic Patients. Thorax, 52, 55-58. http://dx.doi.org/10.1136/thx.52.1.55

[16] Clark, D.J., Grove, A., Cargill, R.I. and Lipworth, B.J. (1996) Comparative Adrenal Suppression with Inhaled Budesonide and Fluticasone Propionate in Adult Asthmatic Patients. Thorax, 51, 262-266.

http://dx.doi.org/10.1136/thx.51.3.262

\section{Abbreviations}

ICS: inhaled corticosteroids

NCS: nasal corticosteroids

FEV-1: forced expiratory volume in 1 second

FVC: forced vital capacity

HPA: hypothalamic-pituitary-adrenal

FP: fluticasone propionate

BDP: budesonate propionate

Anti-IgE: anti-immunoglobulin-E

PEFR: peak expiratory flow rate

HRCT: high resolution computerized scan

HS: hypersensitivity pneumonitis 